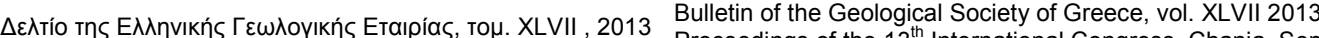
XLVII, 2013 Proceedings of the $13^{\text {th }}$ International Congress, Chania Sept.

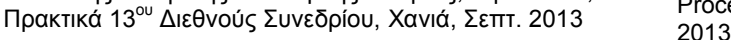

\title{
RE-EXAMINING THE STRESS FIELD OF THE BROADER SOUTHERN AEGEAN SUBDUCTION AREA USING AN UPDATED FOCAL MECHANISM DATABASE
}

\author{
Kkallas Ch. ${ }^{1}$, Papazachos C.B. ${ }^{1}$, Scordilis E.M. ${ }^{1}$ and Margaris B.N. ${ }^{2}$ \\ ${ }^{1}$ Geophysical Laboratory, Aristotle Univ. of Thessaloniki \\ ${ }^{2}$ Institute of Engineering Seismology \& Earthquake Engineering, Thessaloniki
}

\begin{abstract}
We have employed the data of EGELADOS temporary network (October 2005-April 2007) to determine 88 focal mechanism solutions from Southern Aegean Sea using the RAPIDINV algorithm (Cesca et al., 2010). The new focal mechanism solutions determined, complemented with the previously available ones for Southern Aegean Sea provide the basis for a detailed examination of the stress field, using the distribution of $P$ and $T$ axes. To obtain the stress field we applied the method of Gephart and Forsyth (1984), namely the grid search inversion approach of Gephart (1990a,b), which incorporates the $P$ and $T$ axes of selected focal mechanisms. For the inversion, the initial stress solutions were computed by the "average" kinematic $P$ and T-axis approach of Papazachos and Kiratzi (1992). The stress-inversion allows choosing the "ideal" fault plane corresponding to the minimum misfit rotation about an axis of general orientation which is needed to match an observed fault plane/slip direction with one consistent with the final stress model.
\end{abstract}

Key words: Southern Aegean subduction zone, Stress field, Fault plane solutions.

\section{Пєрі́ $\eta \psi \eta$}

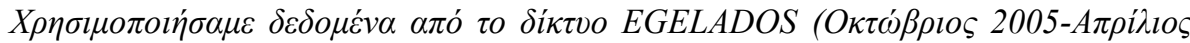

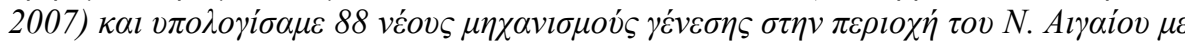

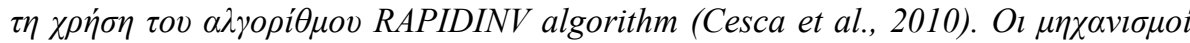

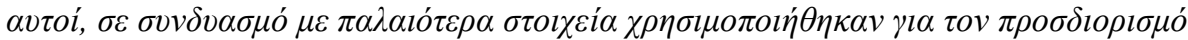

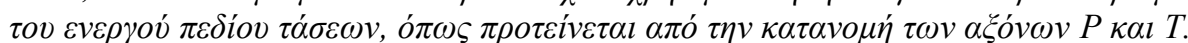

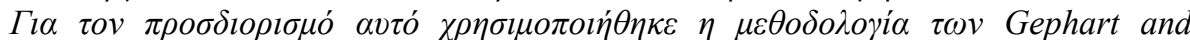

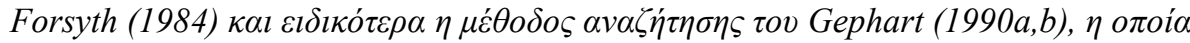

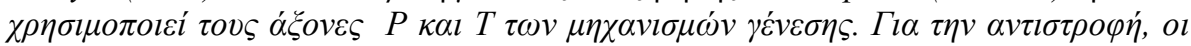

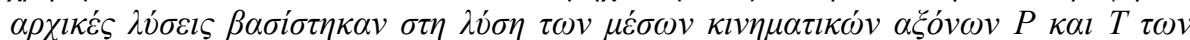

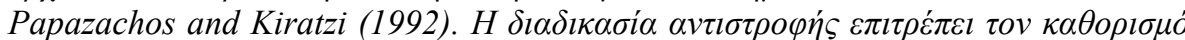

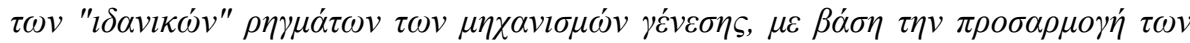

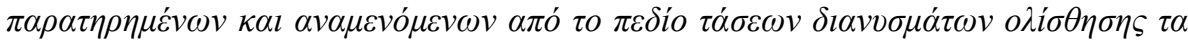

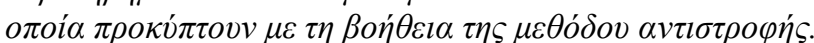

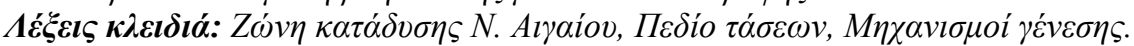




\section{Introduction}

The broader Southern Aegean area (Figure 1) is one of the most active tectonically region of the western Eurasia (Figure 1). In this region, the Nubia lithospheric plate subducts under the Aegean microplate, which in turn overrides the Nubia plate (Papazachos and Comninakis, 1971; McKenzie, 1972). The dominant tectonic feature of the area is Hellenic trench, which runs almost parallel to Hellenic outer sedimentary arc and the inner volcanic arc. The South Aegean deformation is driven primarily by the fast moving $\left(\sim 33 \mathrm{mmyr}^{-1}\right)$ Aegean upper plate overriding a nearly stalled $(\sim 5 \mathrm{~mm}$ mmyr $^{-1}$ ) Nubian lower plate (Ganas and Parson, 2009). A well-developed Benioff zone has been identified (e.g. Papazachos et al., 2000), with medium-to-large transpressional intermediate-depth events, mainly occurring in the depth range of $60-90 \mathrm{~km}$, with maximum depths of the order of $180 \mathrm{~km}$. The subduction is associated with the generation of volcanic activity along the Hellenic volcanic arc in southern Aegean (Fytikas et al, 1985), with the volcanic centre of Santorini in Central Cyclades, being the most active volcano of the area. Much work has been already done on active tectonics of the southern Aegean (Papazachos and Comninakis, 1971; McKenzie, 1970, 1978; Hatzfeld et al., 1989; Benetatos et al., 2004; LePichon et al., 1995; Reilinger et al., 1997; Papazachos, 1999; McClusky et al., 2000; among others). Due to the tectonic complexity of the Aegean Sea we employed recent seismological data from the EGELADOS temporary network (October 2005-April 2007) to study the active tectonics in southern Aegean. Using the data of the EGELADOS temporary network we determined 88 new focal mechanisms, which, in combination with previously published mechanisms, comprise a significant data set, which can be used for the re-evaluation of the stress field of the broader Southern Aegean Sea.

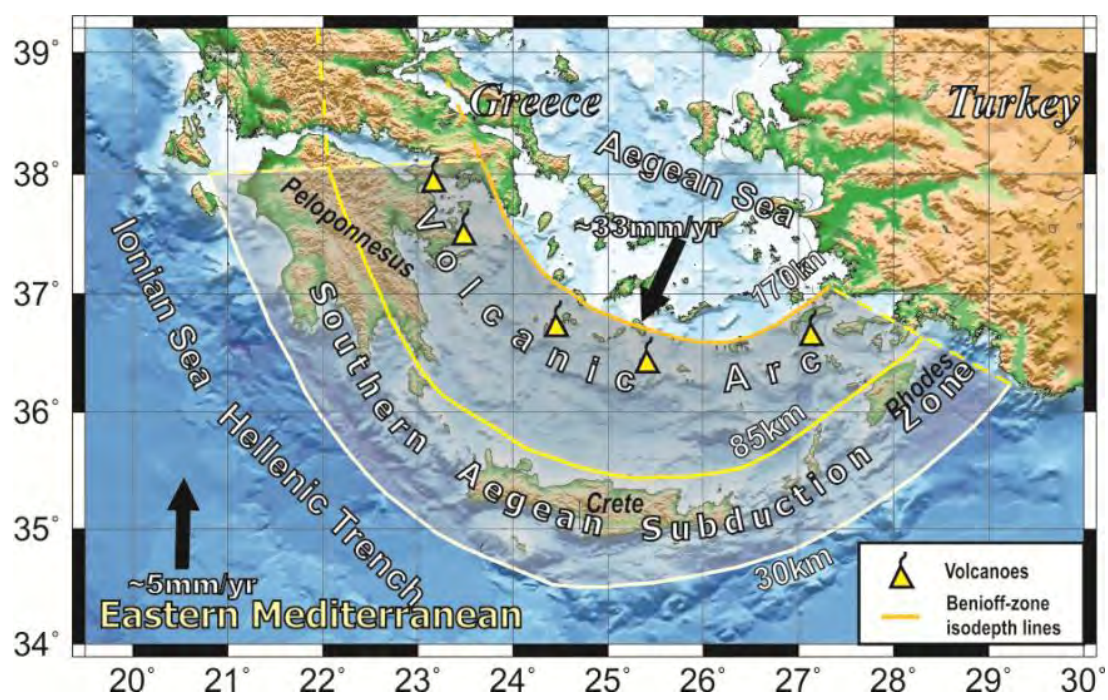

Figure 1 - Schematic geotectonic map of the broader southern Aegean area. Plate motions are depicted by solid vectors. The volcanic arc and the Benioff-zone isodepths are also shown (modified from Papazachos et al. 1998, Karagianni et al., 2005).

\section{Data Used}

The main data source of this work is the EGELADOS temporary network (http://www.gmg.ruhruni-bochum.de/geophysik/seismology/research/egelados.html), (October 2005 - April 2007). EGELADOS (Exploring of the Geodynamics of Subducted Lithosphere Using an Amphibian Deployment of Seismographs) is the largest amphibian seismological network ever deployed in southern Aegean, including 65 land and 24 OBS stations (http://geofon.gfzpotsdam.de/waveform/archive/network.php?net=11), covering almost the entire Hellenic subduction area (Figure 2). We also used data from the Euro Mediterranean Seismological Center 
(EMSC) and Harvard (CMT solutions) databases from 2003 to 2011, as well as solutions published in a large number of previous studies (e.g. Papazachos et al., 1983; Benetatos et al., 2004; Kiratzi and Louvari, 2003; Taymaz et al.,1991; Louvari et al., 1999; Kiratzi et al.,1991; Yilmazturk and Burton, 1999; Arvidsson \& Ekstrom, 1998; Bernard et al., 1997; Louvari et al., 2001; Kiratzi and Louvari, 2003; Vamvakaris et al., 2006).

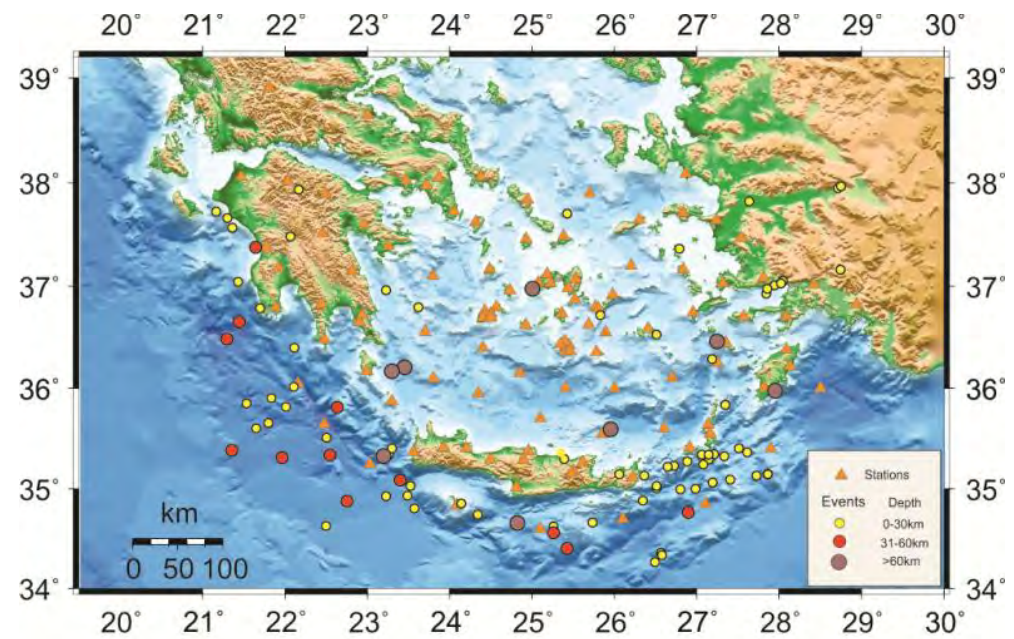

Figure 2 - Station distribution and seismic events for EGELADOS network.

\section{Applied method}

\subsection{Estimation of Fault Plane Solutions}

For the fault plane solution determination from the EGELADOS data, we employed the RAPIDINV processing software (Cesca et al., 2010). RAPIDINV is based on a python module which has been developed in order to simplify the process of kinematic inversion using the Kiwi tools (kinherd.org). The FPS estimation uses both waveform and spectral fitting kinematic inversion (Heimann et al., 2008; Cesca S., et al., 2010), exhibiting model flexibility, a small number of inverted parameters and the possibility for full automation. The main methodological difference is that the method employs a spectral fitting process in the first step, constraining only some of the FPS parameters. The spectral fitting is performed by a grid-walk, a LevenbergMarquadt approach or a combination of both procedures. The Green functions are precomputed and organized in an efficient HDF5 database, allowing the acceleration of the process. Its lower time consumption renders the Kiwi tools suitable for near real-time moment tensor inversion.

After the first step (Figure 3), where the 4 candidate fault planes, depth and moment are determined, a waveform fitting is performed (for any or both type of body waves, surface waves or even full-waveform) to select the final 2 fault planes (Figure 4). Finally, in a third step, a kinematic inversion is performed for an extended source, allowing the selection of the candidate fault-plane and its rupture directivity. The inversion resulted in the determination of focal parameters for 88 earthquakes with a depth range from 2 to $98 \mathrm{~km}$ and moment magnitudes $\mathrm{M}$ ranging from 3.5 to 6.6 . The final data set of the determined fault plane solutions, as well as existing fault plane solutions from previous works, earlier described, is presented in Figure 5.

\subsection{Stress Tensor Inversion}

In order to provide an initial estimate of the stress field variability in the study area, we employed the representative "average focal mechanism tensor" using the approach of Papazachos and Kiratzi (1992). According to this method, an average "focal mechanism" tensor, F, is calculated, which is 


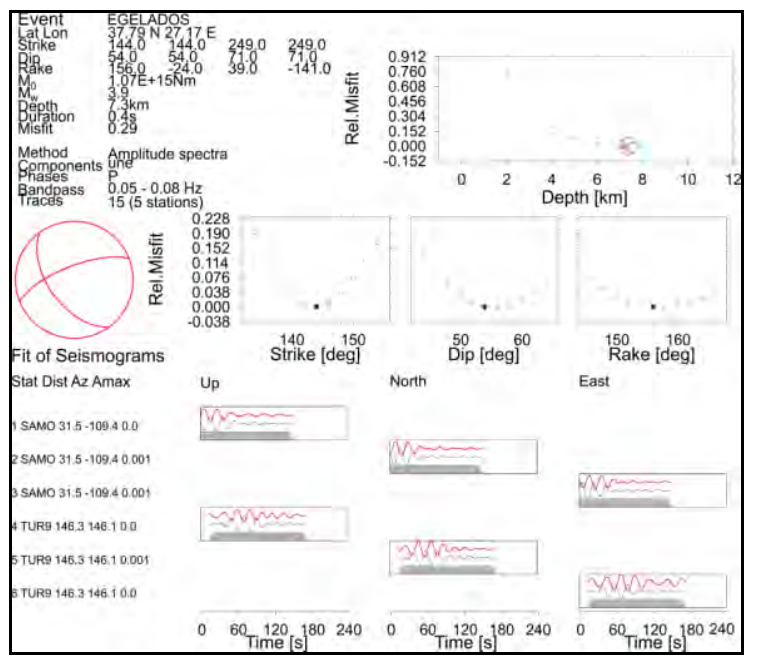

Figure 3 - Sample output of step 1 of the inversion (spectral inversion), where 4 candidate fault planes of the focal mechanism is determined. The retrieved parameters in this step are the fault plane strike, dip, rake, as well as the event $M_{0}$ and event depth.

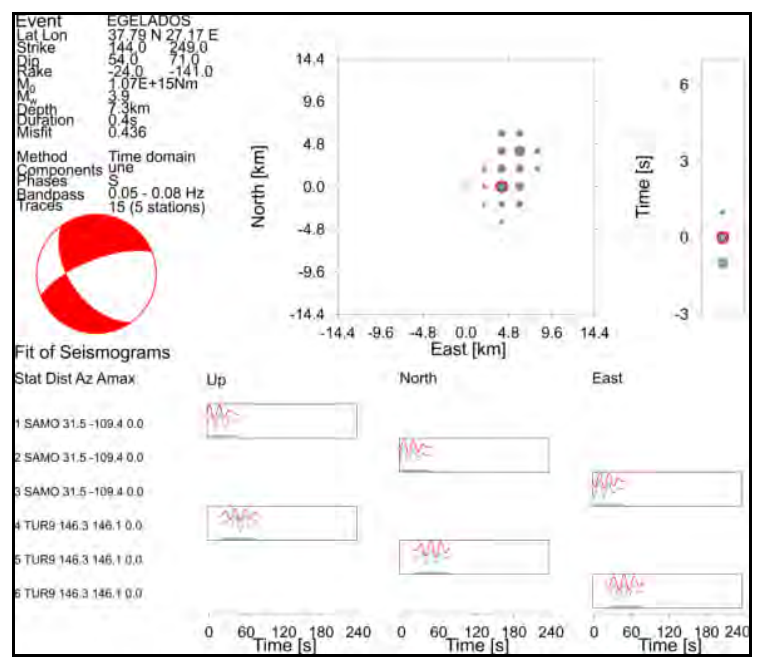

Figure 4 - Sample output step 2 of the inversion (waveform fitting). The waveforms are fit in the time domain, allowing the centroid location (space and time domain) and the retrieval of the compressive/dilatational quadrants.

a function of the strike, $\zeta$, dip, $\delta$, and rake, $\lambda$ of the corresponding fault plane (Aki and Richards, 1980), and the eigenvalues of this average "focal mechanism" tensor F correspond to the average P, $\mathrm{T}$ and $\mathrm{N}$ (null) axes. Therefore, the method defines "average" kinematic ( $\mathrm{P}, \mathrm{T}$ and $\mathrm{N}$ ) axes, which are assumed to be identical with the principal stress axes. In our case data weighting was used depending on the moment magnitude of each event. In order to perform this initial assessment of the stress field in the Southern Aegean Sea by the use of seismological data (Figure 5), we separated the area in smaller sub-regions with common seismotectonic characteristics and a relative fault plane solution homogeneity, so that they can be considered as locally representative.

Figures 6 and 7 present the spatial distribution of the average $P$ and $T$ axes for the depth ranges of 0-30 km and $>30 \mathrm{~km}$, using the Papazachos and Kiratzi (1992) method, while Figure 8 shows the corresponding average focal mechanisms, separated in 5 typical groups. The first two groups (red 


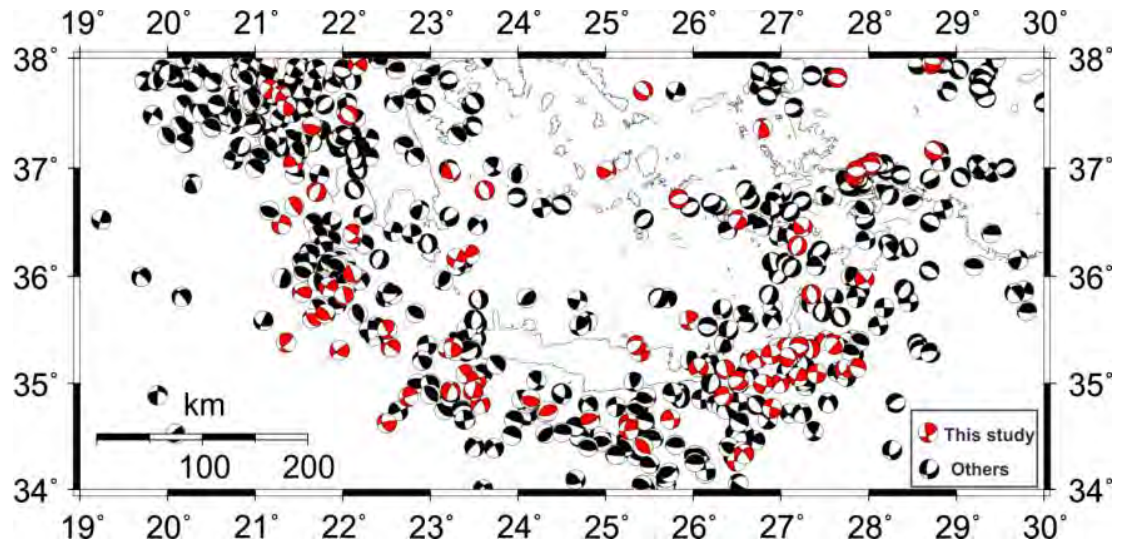

Figure 5 - Distributions of the new (RAPIDINV algorithm - red color) and the previously published (black color) focal mechanism solutions for the Southern Aegean area.

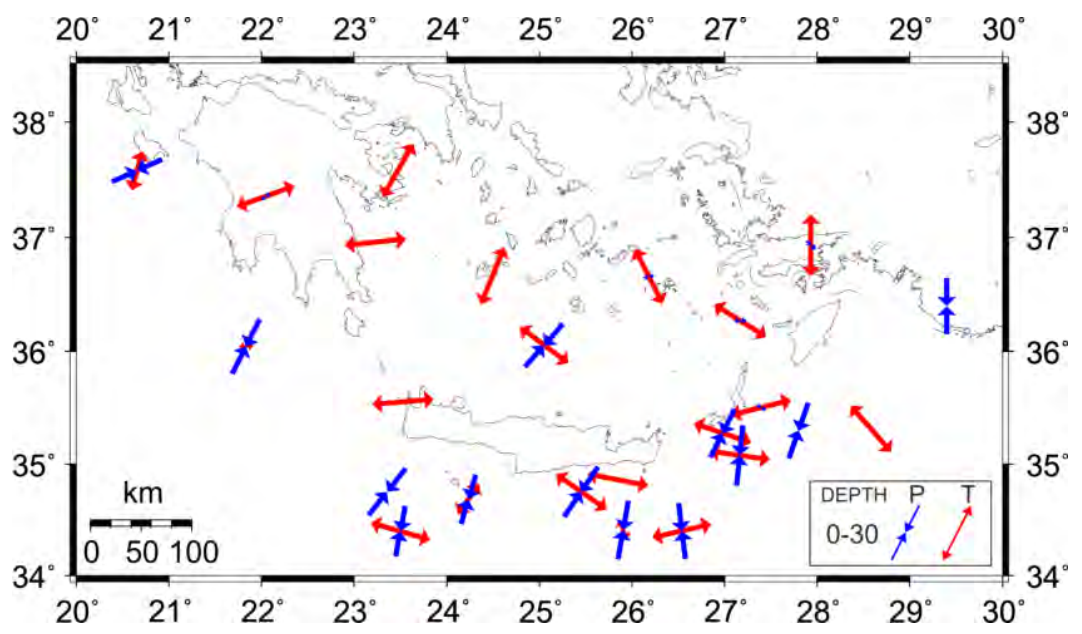

Figure 6 - Horizontal projection of $P$-axes (converging arrows) and $T$-axes (diverging arrows) from the method of the Papazachos and Kiratzi (1992) for the depths of $0-30 \mathrm{~km}$.

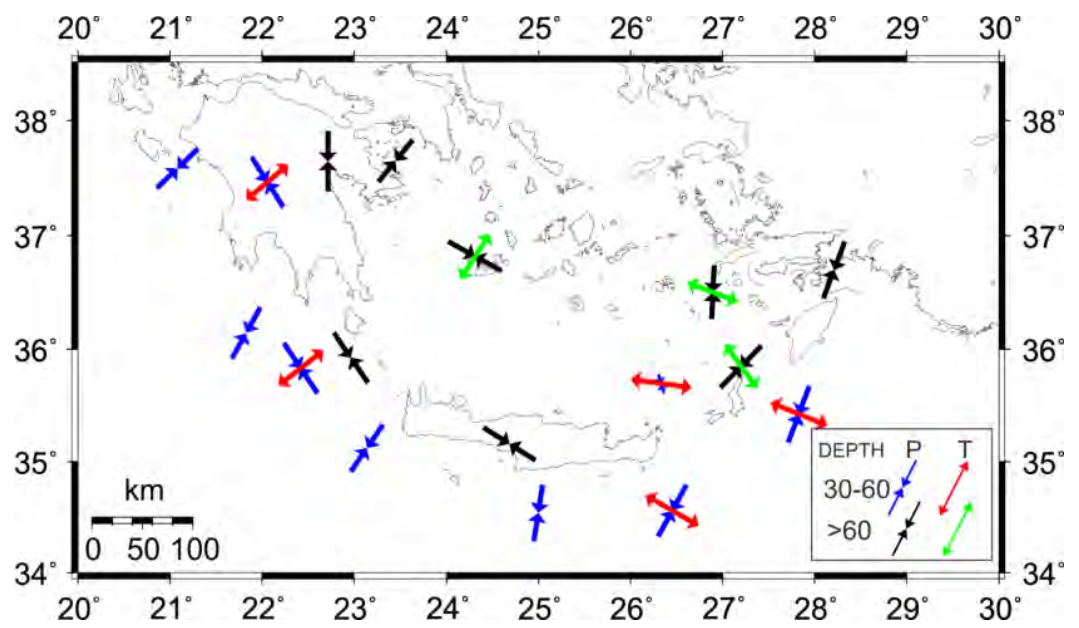

Figure 7 - Horizontal projection of P-axes (converging arrows) and T-axes (diverging arrows) from the method of the Papazachos and Kiratzi (1992) for depths $>30 \mathrm{~km}$. 
and green FPS) corresponds to $\sim \mathrm{E}-\mathrm{W}$ normal faults of the volcanic arc and $\sim \mathrm{N}-\mathrm{S}$ normal faults of the outer (sedimentary) arc, showing a $\sim \mathrm{N}-\mathrm{S}$ and E-W extension field, respectively. The outer arc is characterized by typical thrust faults (blue FPS) that maintain a roughly constant NW-SE orientation, while the brown FPS depict strike-slip events, that mostly cluster along the Strabo and Pliny trenches in the outer SE Aegean arc. Finally, the black FPS correspond to typical transpressional intermediate-depth events, with a clear down-dip extension and arc-parallel compression.

New results can be also inferred for intermediate depth events. Shallower events (close to the outer arc) exhibit a typical down-dip extension and in-slab compression, that shows as early as $30-60 \mathrm{~km}$ for the Peloponnesus and SW Kythira area (see Figure 7), hence at much shallower depths than earlier considered. Extension $\left(\sigma_{3}\right)$ axes become more horizontal at larger depths (Milos and Karpathos groups) and towards Rhodes. The results are somewhat similar to Rondogianni et al. (2011), however the stress changes proposed in the previous work near Rhodes $\left(\sigma_{1}-\sigma_{2}\right.$ interchange with depth) are not detected in this work, where the stress field in Rhodes and Kos (different depth ranges) seems to be quite similar (figures 7 and 8), probably due to the use of extremely large regions by Rondogianni et al. (2011).

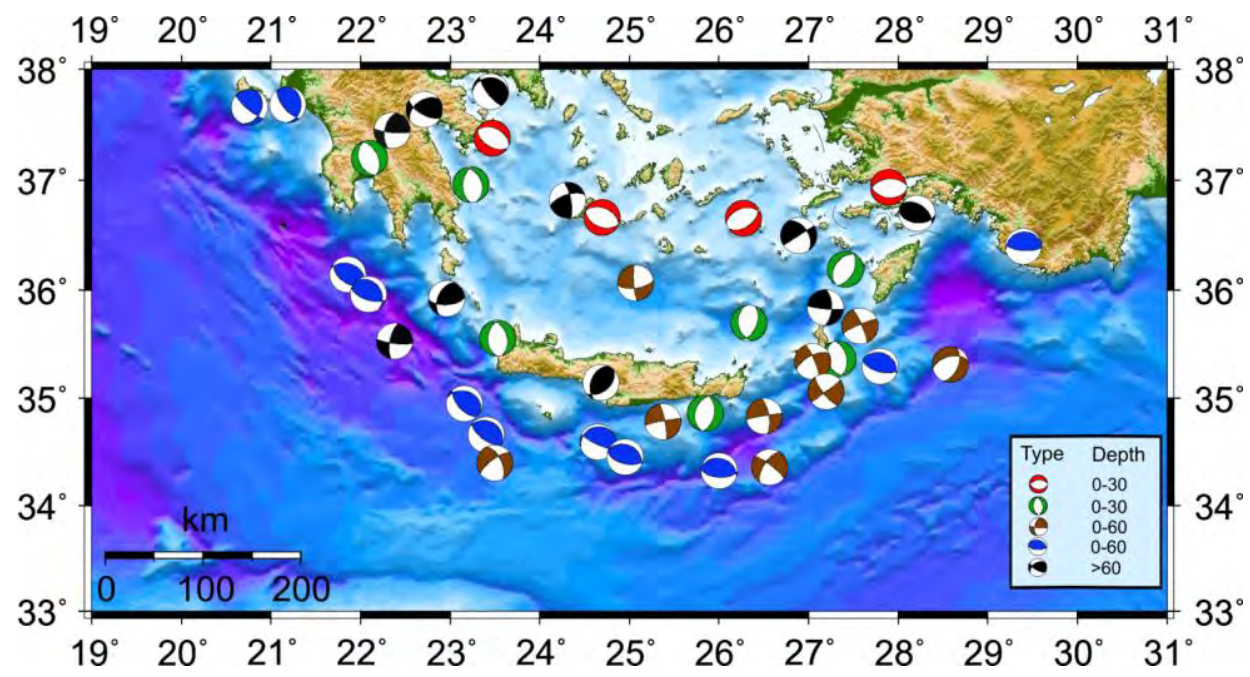

Figure 8 - Average focal mechanisms using the approach of Papazachos and Kiratzi (1992).

In order to confirm the results of Figures 6 and 7, we used the FMSI computer program developed by Gephard and Forsyth (1984) and Gephard (1990a, b) to obtain the stress field from fault plane solutions. In this method the orientation of fault planes and slip directions provided by a large population of earthquake focal mechanisms can be used to determine best fit regional principal stress directions. Four stress parameters are calculated: three of them define the orientation of the main three stress-axes $\sigma_{1}, \sigma_{2}$ and $\sigma_{3}$ and the parameter $\mathrm{R}=\left(\sigma_{2}-\sigma_{1}\right) /\left(\sigma_{3}-\sigma_{1}\right)$, which specifies the magnitude of the intermediate $\sigma_{2}$ compressive stress direction, relative to maximum $\sigma_{1}$ and minimum $\sigma_{3}$ compressive stress directions, under the assumption of uniform stress in the source region. The analysis allows for the possibility that the failure occurs on pre-existing zones of weakness of any orientation. Using this approach we determined the three principal stress directions and the parameter R, as well the associated uncertainty. As initial principal stress solution we used the "average" kinematic ( $\mathrm{P}, \mathrm{T}$ and $\mathrm{N}$ ) axis previously estimated using the approach of Papazachos and Kiratzi (1992). Figures 9 and 10 presents the $P$ and $T$ axes for the $0-30 \mathrm{~km}$ and $>30 \mathrm{~km}$ depth range for the results of the Gephart and Forsyth (1984) method. The obtained results shows very small azimuthal difference for the $\mathrm{P}$ and $\mathrm{T}$ axes between the two methods.

The obtained results from both methods are in excellent agreement with the previous knowledge for the region. The distribution of the focal mechanisms $0-60 \mathrm{~km}$ (blue colour) as shown in Figure 8 , shows thrust faulting that dominates in the outer part of Hellenic trench which starts south of the 
island of Zakynthos, runs along the western part of the Hellenic Arc and extends up to the coasts of Turkey. The P-axes appear to be almost normal to the strike of the arc and sub-parallel to the arc in its eastern part. The distribution of the normal shallow $(0-30 \mathrm{~km})$ focal mechanisms (green colour) running parallel to the thrust zone shows a normal faulting zone with E-W trending T-axes connected with the sedimentary arc (Papazachos et al., 1984; Liotier, 1989; Armijo et al., 1992). An important new feature is that the trend of the normal focal mechanisms along the volcanic arc runs parallel to the local strike of the volcanic arc. At the eastern edge of the arc, near Rhodes island, a dominant zone of strike-slip faulting is identified (brown colour), associated with complex processes of subduction. Strike-slip faulting (black colour) with a significant thrust component is found along subducted Benioff zone, in accordance with earlier studies (e.g. Papazachos et al., 2000, Benetatos et al., 2004), with the P-axes running almost parallel to the strike of the arc. A new feature is that the $T$ axes of deeper events $(>100 \mathrm{~km})$ become almost horizontal under the volcanic arc, not showing down-dip extension as in earlier studies for shallower events $(60-100 \mathrm{~km})$.

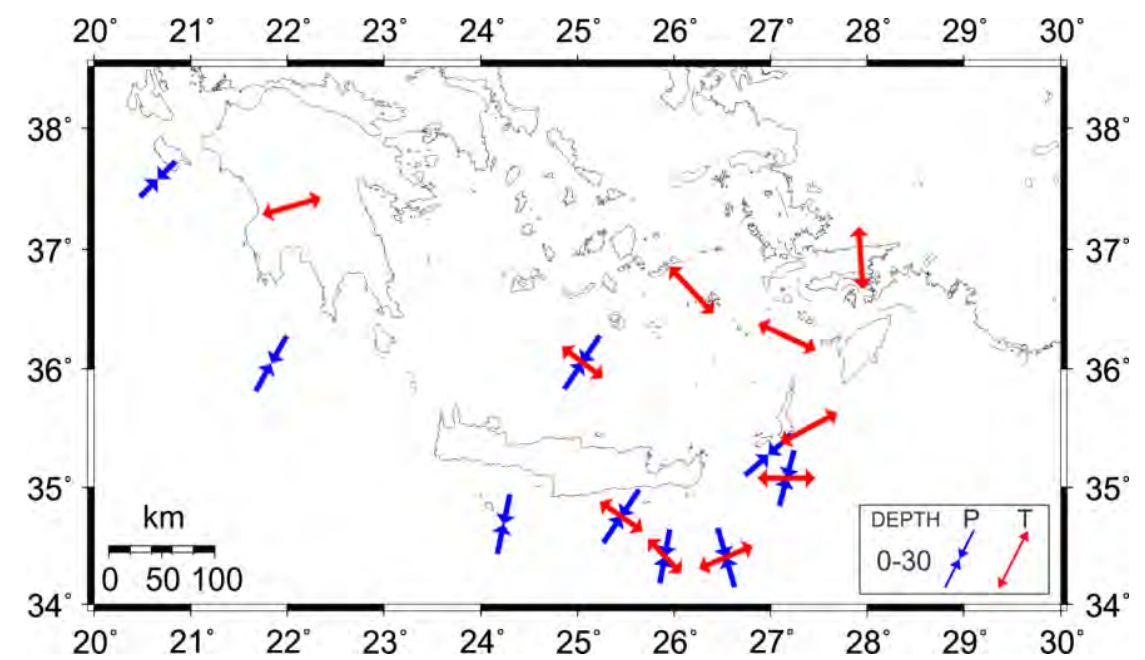

Figure 9 - Horizontal projection of $P$-axes (converging arrows) and $T$-axes (diverging arrows) from the method of the Gephart and Forsyth (1984) for depths $0-30 \mathrm{~km}$.

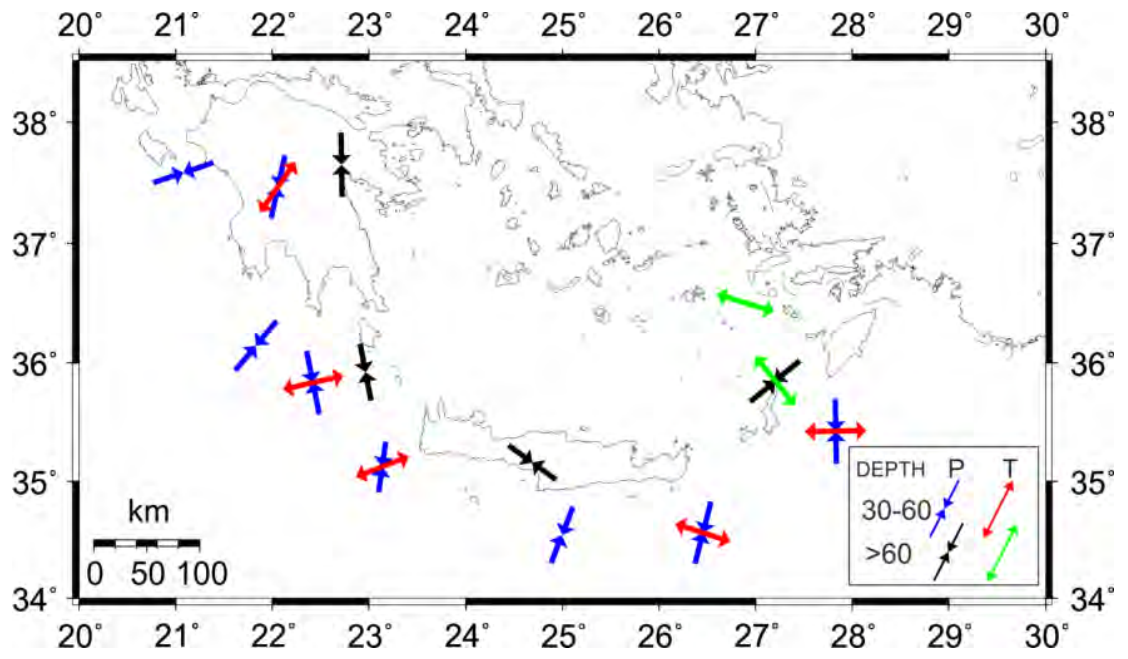

Figure 10 - Horizontal projection of $P$-axes (converging arrows) and T-axes (diverging arrows) from the method of the Gephart and Forsyth (1984) method for depths $>30 \mathrm{~km}$.

$\underline{\text { XLVII, No } 2-569}$ 


\subsection{Fault Determination}

The application of the stress-tensor inversion allowed the determination of the plane corresponding to the minimum misfit rotation around any arbitrary axis which brings one of the nodal planes, its slip direction and the sense of slip into an orientation that is consistent with the stress model. For each FPS the misfit is determined for each modal plane. The nodal plane with the smaller misfit is usually assumed as the "ideal" fault planes on which the corresponding earthquake occurred. However, it is clear that this selection is arbitrary if both nodal planes exhibit similar misfit values which are either small (both planes are acceptable) or very large (both could be considered as "incompatible" with the determined stress field). Taking into account the average FPS solution uncertainty of $10^{\circ}$ for fault planes and $\mathrm{P} / \mathrm{T}$ axes, we considered the difference of the misfit values of the two planes as a quality measure for the selection procedure. In order to obtain more robust results we have assumed that if the misfit calculated for both fault planes (main and auxiliary) is relatively small (typically $<2-3$ times the average uncertainty, i.e. $25^{\circ}$ ) and their difference is less than the average uncertainty $\left(10^{\circ}\right)$, then both planes should be considered and included in the results of this study, as they are practically indistinguishable with respect to their misfit.

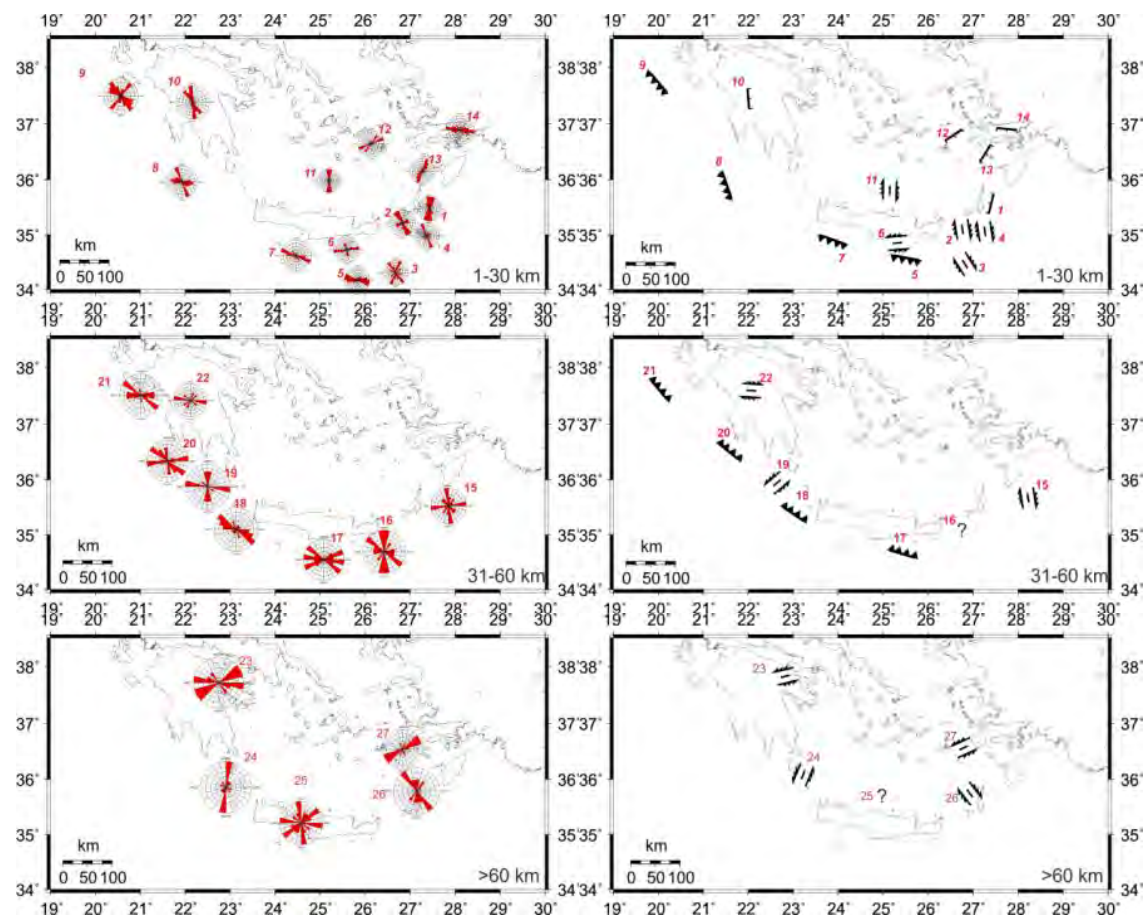

Figure 11 - Fault planes identified by the stress tensor inversion method as candidates for the "actual" seismic faults. The rose diagrams present the corresponding fault distributions.

In Figure 11 the average fault planes from each group identified by the stress inversion are presented as linear elements. The distribution of the identified faults is also presented with a rose diagram. Lund \& Slunga (1999) tested the advantages and disadvantages of the method thoroughly and they concluded that the algorithm of Gephard \& Forsyth (1984) does not always pick the correct nodal plane as fault but in some case the auxiliary plane is picked as fault plane. This clearly occurs for the shallow thrust faults $(0-30 \mathrm{~km})$, as is appears that the Aegean subducts under Nubia plate, contrary to what is observed. This is reversed for deeper thrust events, which show a normal thrusting pattern. An excellent similarity is observed for fault number 11 with results of (Kiratzi, 2012) who to found a prominent N-S strike-slip character of motion for the sequence of January 2012.

$\underline{\text { XLVII. No } 2 \text { - } 570}$ 


\section{Conclusions}

The combined application of both approaches confirm earlier findings and provide a locally novel and more detailed view of the active stress field in the broader Southern Aegean subduction area. In general, 5 main types of faulting and stress patterns are recognized: (a) Thrust faulting at depths up to $60 \mathrm{~km}$ with a dominant NW-SE direction, following the general local trend of the Hellenic arc, with the $\mathrm{P}$ axis having a constant strike, almost perpendicular to the arc-strike in its western and central parts, and sub-parallel to the arc in its eastern part, (b) Normal faulting with T-axes showing $\sim \mathrm{N}-\mathrm{S}$ extension, almost perpendicular to the strike of the volcanic arc at depths up to 30 $\mathrm{km}$, (c) Normal faulting with T-axes showing along - arc extension, running almost parallel to the strike of the arc at depths up to $30 \mathrm{~km}$, (d) Strike-slip faulting with a significant thrust component, corresponding to intermediate-depth events along the subducted Benioff zone, at depths gradually increasing from $50 \mathrm{~km}$ (in the Crete-Kythira area) to $100-120 \mathrm{~km}$ in the southern Aegean volcanic arc region and, (e) Strike-slip faulting near the south-eastern edge of the Hellenic arc up to $60 \mathrm{~km}$. The transition from thrust faulting (group a) to the transpressional intermediate-depth events (group d) occurs at shallower depths under Peloponessus and Kythira than previously considered, while the previously suggested stress-complexity near Rhodes by Rondogianni et al. (2011) is not supported by the present study results.

\section{Acknowledgments}

The GMT system (Wessel and Smith, 1998) was used to plot some figures. This work has been partly supported by the 3D-SEGMENTS project of the ARISTEIA-I call funded by EC European Social Fund and the Greek Secretariat of Research and Technology.

\section{References}

Aki K. and Richards P. 1980. Quantative Seismology: Theory and Methods, Freeman, San Francisco, California, 557 pp.

Baker C., Hatzfeld D., Lyon-Caen H., Papadimitriou E.and Rigo A. 1997. Earthquake mechanisms of the Adriatic Sea and western Greece, Geophys. J. Int. 131, 559-594.

Benetatos C., Kiratzi A., Papazachos C., and Karakaisis G. 2004. Focal mechanisms of shallow and intermediate depth earthquakes along the Hellenic arc, Journal of Geodynamics, 37, 253-296, doi:10.1016/j.jog.2004.02.002

Bird P. 2003. An updated digital model of plate boundaries, Geochemistry Geophysics Geosystems, 4(3), 1027, doi:10.1029/2001GC000252

Cesca S., Buforn E., and Dahm T. 2006. Moment tensor inversion of shallow earthquakes in Spain, Geophys. J. Int., doi: 10.1111/j.1365-246X.2006.03073.x.

Cesca S., Heimann S., Stammler K. and Dahm T. 2010. Automated point and kinematic source inversion at regional distances, J. Geophys. Res., doi:10.1029/2009JB006450.

Ganas A. and Parsons T. 2009. Three-dimensional model of Hellenic Arc deformation and origin of the Cretan uplift, Journal of Geophysical Research, 114: doi: 10.1029/2008JB005599.

Gephart J.W. 1990a. Stress and the direction of slip on fault planes, Tectonics, 9, 845-858.

Gephart J.W. 1990b. FMSI: a FORTRAN program for inverting fault/slickenside and earthquake focal mechanism data to obtain the regional stress tensor, Comput. Geosci. 16 (7), 953-989.

Gephart J. and Forsyth W. 1984. An improved method for determining the regional stress tensor using earthquake focal mechanism data: applications to the San Fernando earthquake sequence, J. Geophys. Res., 89, 9305-9320.

Hatzfeld D., Pedotti G. and Hatzidimitriou R. 1989. The Hellenic subduction beneath the Peloponnesus: First results of a microearthquake study, Earth Planet. Sci. Lett., 93, 283-291.

Heimann S., Cesca S., Krüger F. and Dahm T. 2008. Stable estimation of extended fault properties for medium-sized earthquakes using teleseismic waveform data, Geophysical Research Abstracts, pp. EGU2008- A-07,568.

$\underline{\text { XLVII. No } 2-571}$ 
Karagianni E.E., Papazachos C.B., Panagiotopoulos D.G., Suhadolc P., Vuan A. and Panza G.F. Shear velocity structure in the Aegean area obtained by inversion of Rayleigh waves, Geophys. J. Int., 160, 127-143, 2005.

Kiratzi A., and Louvari E. 2003. Focal mechanisms of shallow earthquakes in the Aegean Sea and the surrounding lands determined by waveform modelling: A new database, Journal of Geodynamics, 36, 251-274; doi:10.1016/S0264-3707(03)00050-4.

Kiratzi A. A. 2013. The January 2012 earthquake sequence in the Cretan Basin, south of the Hellenic Volcanic Arc: focal mechanisms, rupture directivity and slip models, Tectonophysics, 586, 160-172, http://dx.doi.org/10.1016/j.tecto.2012.11.019.

Lund B. and Slunga R. 1999. Stress tensor inversion using detailed microearthquake information and stability constraints: Application to Ölfus in southwest Iceland, J. Geophys. Res., 104:14947-14964.

Le Pichon X., Chamot-Rooke N., Lallemant S., Noomen R. and G. Veis. 1995. Geodetic determination of the kinematics of central Greece with respect to Europe: Implications for eastern Mediterranean tectonics. Journal of Geophysical Research, 100, 12,675-12,690.

Louvari E., Kiratzi A.A. and Papazachos B.C. 1999. The Cephalonia Transform Fault and its extension to western Lefkada Island (Greece), Tectonophysics 308, 223-236.

McKenzie D. 1972. Active tectonics of the Mediterranean region, Geophys. J. R. Astr. Soc. 30, 109-185.

McKenzie D. 1978. Active tectonics of the Alpine-Himalayan belt: the Aegean Sea and surrounding regions, Geophys. J. R. Astr. Soc. 55, 217-254.

McClusky S.S., Balassanian A., Barka C., Demir S., Ergintav I., Georgiev O., Gurkan M., Hamburger K., Hurst H., Kahle K., Kastens G., Kekelidze R., King V., Kotzev O., Lenk S., Mahmoud A., Mishin M., Nadariya A., Ouzounis D., Paradissis Y., Peter M., Prilepin R., Reilinger I., Sanli H. and Seeger A. 2000. Global Positioning System constraints on plate kinematics and dynamics in the eastern Mediterranean and Caucasus, J. Geophys. Res., 105, 5695-5719.

Fytikas M., Innocenti F., Manetti P., Peccerillo A., Mazzuoli R. and Villari L. Tertiary to Quaternary evolution of volcanism in the Aegean region, doi: 10.1144/GSL.SP.1984.017.01.55, Geological Society, London, Special Publications, 17, 687-699, 1984.

Oral M.B., Reilinger R.E., Toksoz M.N., King R.W., Barka A.A., Kiniki J. and Lenk D. 1995. GPS offers evidence of plate motions in eastern Mediterranean, EOS, 76, 9-11.

Papazachos B.C. 1990. Seismicity of the Aegean and the surrounding area, Tectonophysics, 178, 287-308.

Papazachos B.C. and Comninakis P. E. 1971. Geophysical and tectonic features of the Aegean arc, J. Geophys. Res. 76, 8517-8533.

Papazachos B.C., Kiratzi A.A., Hatzidimitriou P.and Rocca A. 1984. Seismic faults in the Aegean area, Tectonophysics, 106, 71-85.

Papazachos B.C. and Papazachou C.B. 1997. The earthquakes of Greece. Ziti Publ. Thessaloniki, Greece, 304pp.

Papazachos B.C., Papadimitriou E.E., Kiratzi A.A., Papazachos C.B. and Louvari E.K. 1998. Fault plane solutions in the Aegean sea and the surrounding area and their tectonic implications, Bolletino di Geofisica Teorica ed Applicata, 39, 199-218.

Papazachos B.C., Karakostas V.G., Papazachos C.B.and Scordilis E.M. 2000. The geometry of the Wadati-Benioff zone and the lithospheric kinematics in the Hellenic arc, Tectonophysics, $319,275-300$.

Papazachos C.B. and Kiratzi A.A. 1992. A formulation for reliable estimation of active crustal deformation and its application to central Greece, Geophys. J. Int., 111, 424-432.

Papazachos C.B. and Kiratzi A.A., A formulation for reliable estimation of active crustal deformation and its application to central Greece, Geophys. J. Int., 111, 424-432., 1992.

Papazachos C.B. 1999. Seismological and GPS evidence for the Aegean-Anatolia interaction, Geophys. Res. Lett., 17, 2653-2656. 
Reilinger R.E., McClusky S.C., Oral M.B., King R.W., Toksoz M.N., Barka A.A., Kinik I., Lenk O. and Sanli I. 1997. Global positioning system measurements of present-day crustal movements in the Arabia-Africa-Eurasia plate collision zone, J. Geophys. Res., 102, 9983-9999.

Rontogianni S., Konstantinou N.S., Melis C.P. Evangelidis Slab stress field in the Hellenic subduction zone as inferred from intermediate-depth earthquakes (2011), Earth, Planets and Space, 63 (2), 139-144.

Taymaz T., Jackson J.and McKenzie D. 1991. Active tectonics of the north and central Aegean Sea, Geophys. J. Int., 106, 433-490.

Yilmazturk A. and Burton P.W. 1999. Earthquake source parameters as inferred from body waveform modeling, southern Turkey, J. Geodynamics, 27, 469-499. 


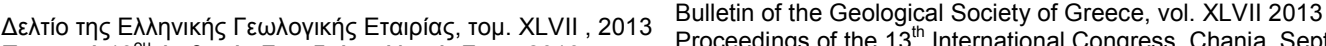

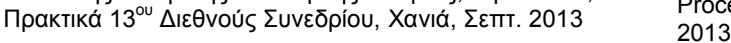

\title{
THE GEOTECTONIC EVOLUTION OF OLYMPUS MT. AND ITS MYTHOLOGICAL ANALOGUE
}

\author{
Mariolakos D.I. ${ }^{1}$ and Manoutsoglou E. ${ }^{2}$ \\ ${ }^{I}$ National and Kapodistrian University of Athens, Faculty of Geology and Geoenvironment, \\ Department of Dynamic, Tectonic \& Applied Geology, Panepistimioupoli, Zografou, GR 157 84, \\ Athens, Greece,mariolakos@geol.uoa.gr \\ ${ }^{2}$ Technical University of Crete, Department of Mineral Resources Engineering, Research Unit of \\ Geology, Chania, 73100, Greece, emanout@mred.tuc.gr
}

\begin{abstract}
Mt Olympus is the highest mountain of Greece $(2918 \mathrm{~m}$.) and one of the most important and well known locations of the modern world. This is related to its great cultural significance, since the ancient Greeks considered this mountain as the habitat of their Gods, ever since Zeus became the dominant figure of the ancient Greek religion and consequently the protagonist of the cultural regime. Before the generation of Zeus, Olympus was inhabited by the generation of Cronus.

In this paper we shall refer to a lesser known mythological reference which, in our opinion, presents similarities to the geotectonic evolution of the wider area of Olympus.

According to Apollodorus and other great authors, the God Poseidon and Iphimedia had twin sons, the Aloades, namely Otus and Ephialtes, who showed a tendency to gigantism. When they reached the age of nine, they were about $16 \mathrm{~m}$. tall and $4.5 \mathrm{~m}$. wide. Having then realized their powers, because of their gigantic proportions, they decided to climb Olympus and fight the Gods, exile Zeus and the others, and wed two Goddesses. Otus was to marry Hera and Ephialtes Artemis.

But they did not know how to climb such a high mountain, so they decided to construct a "ladder", by putting mount Ossa on top of mount Olympus and mount Pelion on top of Ossa. This description coincides with the geological and tectonic evolution of the wider Olympus area. But, these complex tectonic processes were completed about 8 - 10 m.a., i.e. millions of years before the appearance of humans, therefore it is impossible that these morphotectonic processes were witnessed by man, so the similarities between the myth of Aloades and the tectonic evolution of the area must be purely coincidental. But are they, or is there more here?
\end{abstract}

Key words: Aloades, Otus, Ephialtes, Pilion, Ossa.

\section{Пєрі́ $\eta \psi \eta$}

O 'O

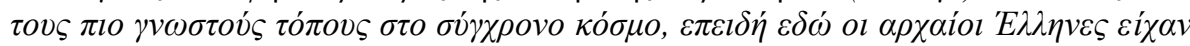

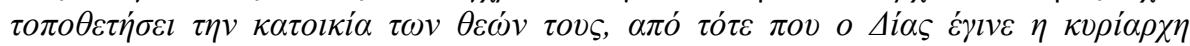

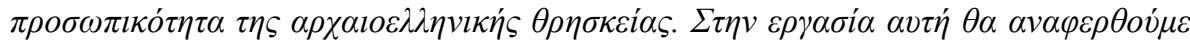

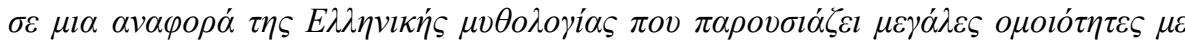

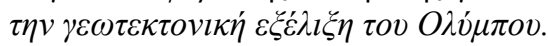

$\underline{\text { XLVII. No } 2-574}$ 